\title{
ОПРЕДЕЛЕНИЕ КОБАЛЬТА МЕТОДОМ КАТОДНОЙ ВОЛЬТАМПЕРОМЕТРИИ
}

Лейтес Е.А., Ширшова Е.Ф.

ФГБОУ ВПО Алтайский государственный университет, Барнаул, Россия

leites-elena@yandex.ru

DOI: 10.26902/ASFE-11_167

Для определения кобальта используют ряд физико-химических методов: фотометрических, атомно-абсорбционный, атомно-эмиссионный с индуктивно связанной плазмой, потенциометрический, вольтамперометрический. Известные методики вольтамперометрического определения кобальта (II) предполагают, в основном, применение ртутьсодержащих индикаторных электродов, поэтому практическое значение имеет разработка вольтамперометрических методик определения кобальта (II) с применением электродов другог типа. При этом стоит обращать внимание на стоимость, экспрессность и экологическую безопасность анализа.

Целью данной работы является разработка методики определения кобальта методом катодной вольтамперометрии на углеродистом электроде.

В качестве фоноого раствора для изучения поведения кобальта выбран универсальный буферный раствор Бриттона-Робинсона, который позволяет получить растворы с диапазоном $\mathrm{Ph}$ от 1.81 до 11.98 .

Пик кобальта (II) методом катодной вольтамперометрии зарегистрирован на фоне универсального буферного раствора при потенциале $+0,45$ В. Наибольшую величину аналитического сигнала получили при $\mathrm{pH}=11,98$, что и использовали для исследования. Наибольшие значения тока пика регистрируются пр начальном потенциале в интервале $(0,70$ - 1,00) В с максимальным значением тока пика при потенциале равном 0,80 В. При потенциалах начала развертки меньше 0,60 В и больше 1,15 В сигнал кобальта практически не выражен. При данных условиях кобальт можно определять в интервале концентраций $\mathrm{n} \cdot 10^{-3}-$ $\mathrm{n} \cdot 10^{-4} \mathrm{M}$.

Из литературных данных известно, что в присутствии комплексообразующих веществ в растворе можно снизить определяемую концентрацию исследуемого компонента. Для опредления кобальта в качестве комплексообразующего вещества выбран антипирин. При добавлении в исследуемый раствор кобальта антипирина происходит увеличение тока пика кобальта. Антипирин может оказывать такое влияние, возможно, за счет адсорбции его или его комплексного соединения с кобальтом на поверхности электрода, приводящее к облегчению электровосстановления кобальта (II) на поверхности электрода.

В присутствии антипирина при рН 8,00 - 9,00 ток пика кобальта в присутствии антипирина наибольший. Показано, что в присутствии антипирина определяемая концентрация кобальта может быть снижена и составляет $n \cdot 10^{-6} \mathrm{M}$. 